\title{
Corynebacterium mooreparkense, a later heterotypic synonym of Corynebacterium variabile
}

Correspondence

Roberto Gelsomino

Roberto.Gelsomino@Ugent.be

\author{
Roberto Gelsomino, ${ }^{1}$ Marc Vancanneyt, ${ }^{1}$ Cindy Snauwaert, ${ }^{1}$ \\ Katrien Vandemeulebroecke, ${ }^{1}$ Bart Hoste, ${ }^{1}$ Timothy M. Cogan ${ }^{2}$ \\ and Jean Swings ${ }^{1}$
}

\author{
${ }^{1}$ BCCM/LMG Bacteria Collection, Laboratorium voor Microbiologie, Universiteit Gent, \\ Ledeganckstraat 35, Gent, Belgium \\ ${ }^{2}$ Dairy Products Research Centre, Teagasc, Fermoy, Ireland
}

Corynebacterium mooreparkense (LMG S-19265 ${ }^{\mathrm{T}}=\mathrm{LMG}$ $19265^{\mathrm{T}}=$ NCIMB $30131^{\mathrm{T}}=$ DPC $5310^{\mathrm{T}}$ ) is a species whose strains were isolated from an Irish smear-ripened cheese (Gubbeen) and was described by Brennan et al. (2001). Ten isolates were assigned to the species by these authors: DPC 5305, DPC 5306, DPC 5307, DPC 5308, DPC 5309, DPC 5312, DPC 5313, DPC 5314, DPC 5315 and DPC $5310^{\mathrm{T}}$. The type strain was originally deposited in the BCCM/LMG Bacteria Collection as LMG S- $19265^{\mathrm{T}}$ and at the National Collection of Industrial and Marine Bacteria as NCIMB $30131^{\mathrm{T}}$.

During a recent research project, the surface microflora of Gubbeen was again thoroughly studied. A first screening method consisted of comparing the band patterns obtained with rep-PCR by using primer BOXA1R (Versalovic et al., 1994). Twenty-five cheese-surface isolates showed a similar band pattern with the type strain of C. mooreparkense. However, all band patterns were also very similar to those of strains of Corynebacterium variabile (LMG $22560^{\mathrm{T}}$, LMG 22561 and LMG 22562). This peculiar result persuaded us to ask the author of the $C$. mooreparkense description to

Published online ahead of print on 23 December 2004 as DOI 10.1099/ijs.0.63420-0.

The GenBank/EMBL/DDBJ accession numbers for the 16S rRNA gene sequences of LMG $19265^{\top}$ and LMG $22560^{\top}$ are AJ783438 and AJ767054, respectively. send us all ten above-mentioned DPC isolates and we requested from NCIMB the strain deposited in their culture collection (NCIMB 30131 $1^{\mathrm{T}}$ ). rep-PCR was repeated with all these strains. Fig. 1 shows that the rep-PCR band patterns obtained with primer BOXA1R of C. mooreparkense strains DPC 5305 to DPC $5310^{\mathrm{T}}$ (LMG 19265 ${ }^{\mathrm{T}}$ ) and NCIMB $30131^{\mathrm{T}}$ are very similar to those of C. variabile strains and some recent Gubbeen isolates (numerical analysis was performed by using the Pearson coefficient and the UPGMA dendrogram type with the Bionumerics software; Applied Maths).

Representatives of these isolates were compared by SDSPAGE of whole-cell proteins, a method that has been proven to differentiate on the species level (Pot et al., 1994; Kersters \& De Ley, 1975). Fig. 2 shows that there is no significant difference between both the type strains and other isolates of C. mooreparkense and C. variabile. Moreover, two recent representative isolates from Gubbeen cheese (LMG 22338 and LMG 22363) also show high similarity with $C$. variabile and C. mooreparkense (numerical analysis with Pearson coefficient and UPGMA dendrogram type using the GelCompar software; Applied Maths).

Next, we tried to collect all type strains of $C$. mooreparkense from the different institutes involved in the original description or available in other culture collections. The University of Newcastle, where the 16S rRNA gene 

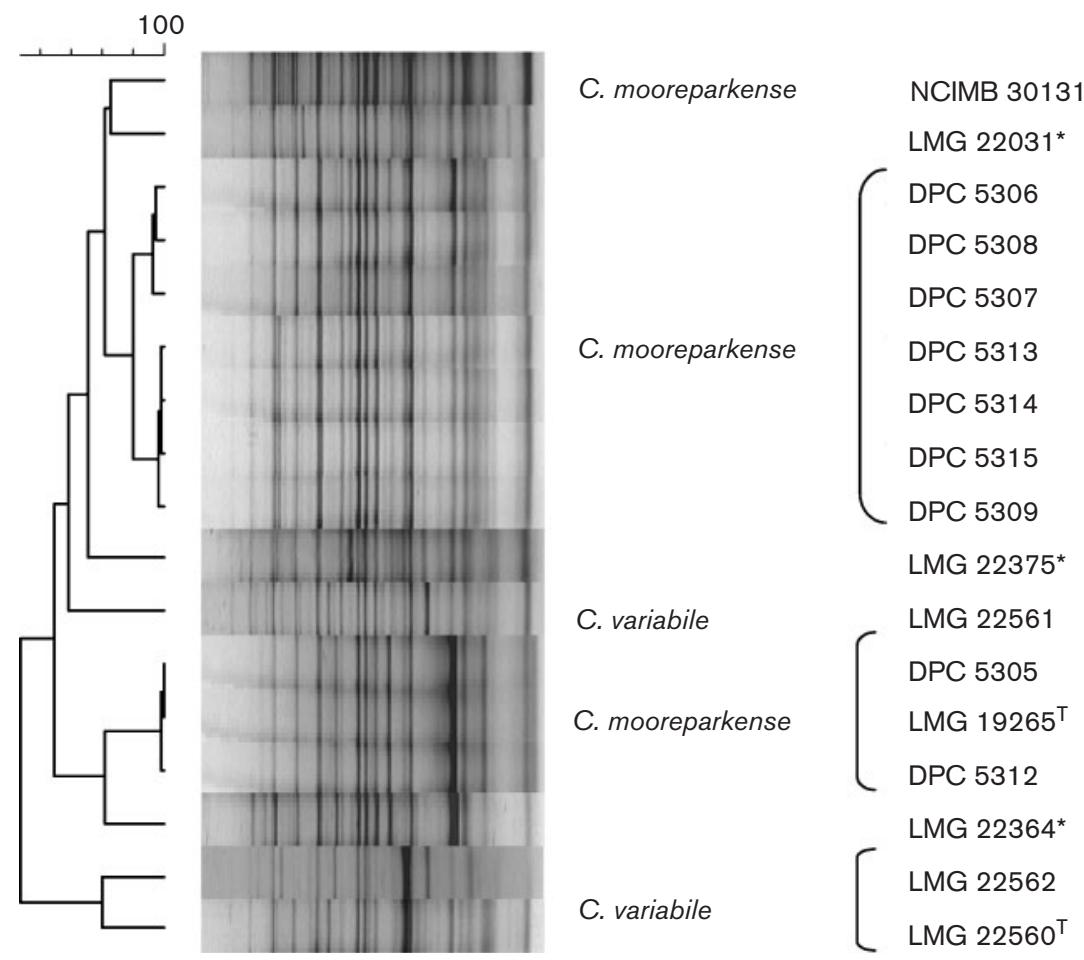
Fig. 1. rep-PCR patterns obtained with primer BOXA1R of the ten DPC strains described by Brennan et al. (2001), NCIMB $30131^{\top}$, representative cheese isolates and C. variabile strains [cheese isolates with *, strains isolated recently (2003) from Gubbeen cheese].

sequencing was performed, and the Deutsche Sammlung von Mikroorganismen und Zellkulturen (DSMZ), where the DNA-DNA hybridization was performed, were contacted. However, these research groups disposed of the strain after analysis. The ten strains from the DPC collection and NCIMB $30131^{\mathrm{T}}$ were therefore used for partial ( 570 bp) 16S rRNA gene sequences. All strains showed a similarity of at least $99.5 \%$ among each other (data not shown) and with the newly determined complete sequence of C. mooreparkense LMG $19265^{\mathrm{T}}$ (GenBank/EMBL/DDBJ accession no. AJ783438), the type strain of C. variabile LMG $22560^{\mathrm{T}}$ sequenced in our laboratory (AJ767054) and the deposited sequence of C. variabile NCDO $2097^{\mathrm{T}}$ (X53185). However, a similarity of only $96.6 \%$ was obtained with the original sequence of $C$. mooreparkense LMG $19265^{\mathrm{T}}$ (AF267148) of Brennan et al. (2001) (Fig. 3). This could be explained by mistakes during the sequencing procedure, which resulted in many inserts that inexplicably can be found in the 16S rRNA gene sequences of DPC 5305, DPC
5307, DPC 5315 and DPC 5310 ${ }^{\mathrm{T}}$ (GenBank/EMBL/DDBJ accession nos AF267149, AF267151, AF267150 and AF267148, respectively) but cannot be found in any other strain of C. mooreparkense when re-sequenced in our laboratory.

In a following step, DNA-DNA hybridizations between $C$. variabile $\mathrm{LMG} 22560^{\mathrm{T}}$ and C. mooreparkense LMG $19265^{\mathrm{T}}$ were performed. The $\mathrm{G}+\mathrm{C}$ content of the DNA was determined by HPLC (Mesbah et al., 1989) using the further specifications given by Logan et al. (2000). DNA-DNA hybridization was performed by using a modification of the microplate method of Ezaki et al. (1989), as described by Willems et al. (2001). A hybridization temperature of $47^{\circ} \mathrm{C}$ (calculated with correction for the presence of $50 \%$ formamide) was used. A relatedness of $95 \%$ between LMG $22560^{\mathrm{T}}$ and LMG $19265^{\mathrm{T}}$ was obtained (reciprocal values of 91.4 and $98.9 \%$ ), thus assigning the two strains to a single species, according to the recommendations for

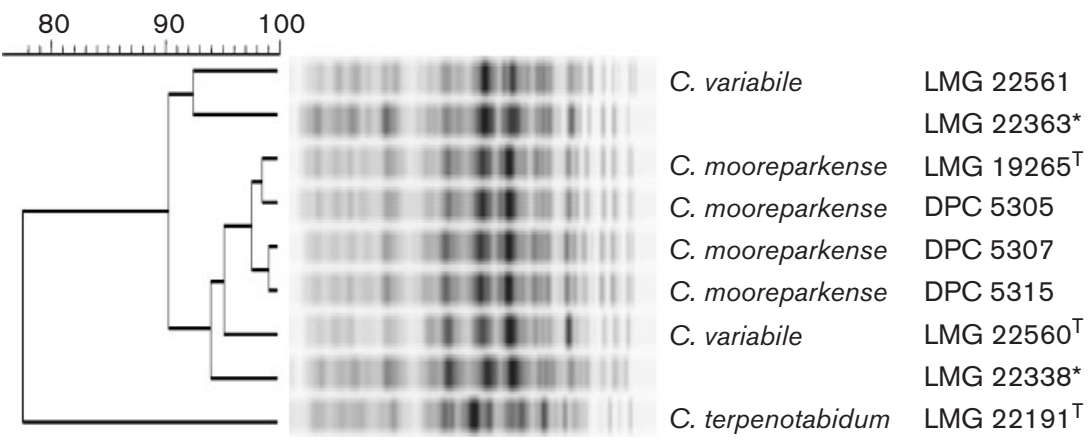

Fig. 2. SDS-PAGE band patterns and corresponding dendrogram of representative isolates of C. mooreparkense and C. variabile [cheese isolates with *, strains isolated recently (2003) from Gubbeen cheese]. 


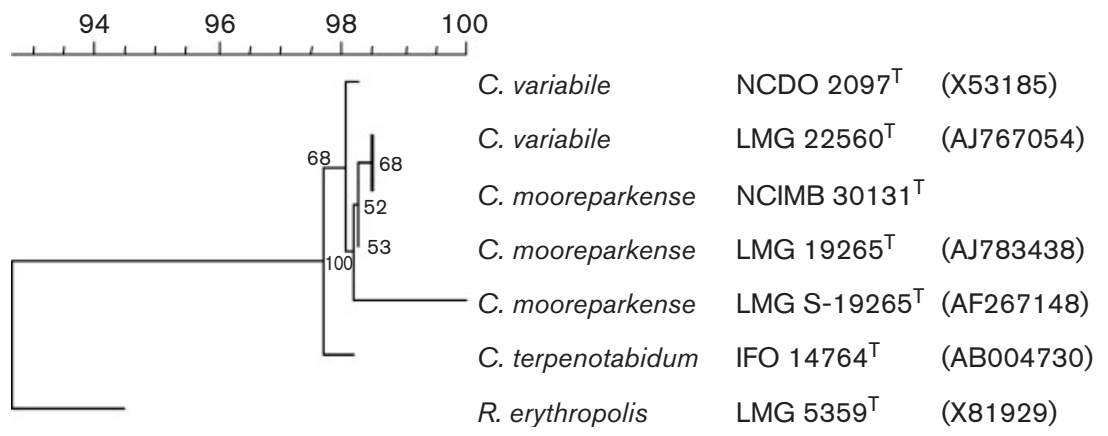

Fig. 3. Phylogenetic relationships of $C$. variabile, C. mooreparkense and their closest neighbours based on neighbourjoining analysis of the 16S rRNA gene sequences. Bootstrap values (expressed as percentages of 1000 replications) are shown at branch points. C., Corynebacterium; R., Rhodococcus.

species designation (Wayne et al., 1987; Stackebrandt et al., 2002). This value is in contradiction with the value obtained by Brennan et al. (2001), who state that the level of DNA re-association is $26 \%$.

We conclude that the strains described as C. mooreparkense match the genomic characteristics of $C$. variabile and that C. mooreparkense must therefore be seen as a later heterotypic synonym of $C$. variabile.

\section{Acknowledgements}

The authors wish to acknowledge the European Community's project Smear Cheese Microflora 'QLK1-CT-2001-02228'.

\section{References}

Brennan, N. M., Brown, R., Goodfellow, M., Ward, A. C., Beresford, T. P., Simpson, P. J., Fox, P. F. \& Cogan, T. M. (2001). Corynebacterium mooreparkense sp. nov. and Corynebacterium casei sp. nov., isolated from the surface of a smear-ripened cheese. Int J Syst Evol Microbiol 51, 843-852.

Ezaki, T., Hashimoto, Y. \& Yabuuchi, E. (1989). Fluorometric deoxyribonucleic acid-deoxyribonucleic acid hybridization in microdilution wells as an alternative to membrane filter hybridization in which radioisotopes are used to determine genetic relatedness among bacterial strains. Int J Syst Bacteriol 39, 224-229.
Kersters, K. \& De Ley, K. (1975). Identification and grouping of bacteria by numerical analysis of their electrophoretic protein patters. J Gen Microbiol 87, 333-342.

Logan, N. A., Lebbe, L., Hoste, B. \& 7 other authors (2000). Aerobic endospore-forming bacteria from geothermal environments in northern Victoria Land, Antarctica, and Candlemas Island, South Sandwich archipelago, with the proposal of Bacillus fumarioli sp. nov. Int J Syst Evol Microbiol 50, 1741-1753.

Mesbah, M., Premachandran, U. \& Whitman, W. B. (1989). Precise measurement of the $\mathrm{G}+\mathrm{C}$ content of deoxyribonucleic acid by highperformance liquid chromatography. Int J Syst Bacteriol 39, 159-167.

Pot, B., Vandamme, P. \& Kersters, K. (1994). Analysis of electrophoretic whole-organism protein fingerprints. In Chemical Methods in Prokaryotic Systematics, pp. 493-521. Edited by M. Goodfellow \& A. G. O'Donnell. Chichester, UK: Wiley.

Stackebrandt, E., Frederiksen, W., Garrity, G. M. \& 10 other authors (2002). Report of the ad hoc committee for the re-evaluation of the species definition in bacteriology. Int J Syst Evol Microbiol 52, 1043-1047.

Versalovic, J., Schneider, M., de Bruijn, F. J. \& Lupski, J. R. (1994). Genomic fingerprinting of bacteria using repetitive sequence-based polymerase chain reaction. Methods Mol Cell Biol 5, 25-40.

Wayne, L. G., Brenner, D. J., Colwell, R. R. \& 9 other authors (1987). International Committee on Systematic Bacteriology. Report of the ad hoc committee on reconciliation of approaches to bacterial systematics. Int J Syst Bacteriol 37, 463-464.

Willems, A., Doignon-Bourcier, F., Goris, J., Coopman, R., de Lajudie, P., De Vos, P. \& Gillis, M. (2001). DNA-DNA hybridization study of Bradyrhizobium strains. Int $J$ Syst Evol Microbiol 51, 1315-1322. 